\title{
Expression of the oncogenic, constitutive active Platelet-Derived Growth Factor Receptor alpha D842V mutant induces loss of primary cilia
}

\author{
BS Nielsen", F Schmid, R Malinda, ST Christensen, LB Pedersen \\ From Cilia 2014 - Second International Conference \\ Paris, France. 18-21 November 2014
}

\section{Objective}

The receptor tyrosine kinase (RTK) Platelet-Derived Growth Factor Receptor $\alpha$ (PDGFR $\alpha$ ) localizes to the primary cilium, and expression of the constitutive active PDGFR $\alpha$ D 842 V mutant has been linked to gastrointestinal tumor formation. We set out to investigate whether expression of D842V causes loss of primary cilia in cultured cells.

\section{Methods}

Plasmids encoding GFP-tagged wild type and D842V mutant PDGFR $\alpha$ were expressed in hTERT-RPE1 cells. To promote ciliogenesis, transfected cells were grown under serum-free conditions for 12 hours and in the presence of various inhibitors. Cilia numbers of GFPpositive cells were assessed by immunofluorescence microscopy with antibodies against cilia markers. In parallel, cells were analyzed by western blotting to evaluate expression level and activity of the tagged receptors.

\section{Results}

Cells expressing the D842V mutant contained significantly fewer cilia than cells expressing wild type PDGFR $\alpha$. Cilia numbers of D842V-expressing cells were restored to control levels upon treatment with the RTK inhibitor crenolanib, but not with other RTK inhibitors such as AG1296 or imatinib. Western blot analysis confirmed that D842V activity is inhibited by crenolanib, but not by AG1296 and imatinib. Treatment with inhibitors against AKT, ERK1/2 and HDAC6 failed to restore cilia numbers in D842Vexpressing cells, suggesting that the $\mathrm{D} 842 \mathrm{~V}$ mutant induces cilium loss by an alternate pathway.

Department of Biology, University of Copenhagen, Copenhagen, Denmark

\section{Conclusions}

Our results indicate that the D842V mutant promotes loss of primary cilia by a mechanism that depends on its kinase activity, but not on activation of AKT, ERK1/2 or HDAC6. We are currently investigating the mechanism by which $\mathrm{D} 842 \mathrm{~V}$ induces loss of cilia.

Published: 13 July 2015

\section{doi:10.1186/2046-2530-4-S1-P63}

Cite this article as: Nielsen et al: Expression of the oncogenic,

constitutive active Platelet-Derived Growth Factor Receptor alpha D842V mutant induces loss of primary cilia. Cilia 2015 4(Suppl 1):P63.

\section{Submit your next manuscript to BioMed Central and take full advantage of: \\ - Convenient online submission \\ - Thorough peer review \\ - No space constraints or color figure charges \\ - Immediate publication on acceptance \\ - Inclusion in PubMed, CAS, Scopus and Google Scholar \\ - Research which is freely available for redistribution

